This is the final peer-reviewed accepted manuscript of:

Marco Albertini, Giancarlo Gasperoni e Debora Mantovani, Whom to Help and Why? Family Norms on Financial Support for Adult Children among Immigrants, "Journal of Ethnic and Migration Studies" (ISSN 1369-183X), vol. 45, n. 10, 2019, pp. 1769-1789

The final published version is available online at:

doi.org/10.1080/1369183X.2018.1485206

Rights / License:

The terms and conditions for the reuse of this version of the manuscript are specified in the publishing policy. For all terms of use and more information see the publisher's website.

This item was downloaded from IRIS Università di Bologna (https://cris.unibo.it/)

When citing, please refer to the published version. 


\title{
Whom to help and why? Family norms on financial support for adult children among immigrants
}

\author{
Albertini, Marco; Gasperoni, Giancarlo; Mantovani, Debora ${ }^{1}$ \\ Department of Political and Social Sciences, Alma Mater Studiorum - Università di Bologna
}

\begin{abstract}
Financial support for children of immigrant origin, even after they have grown up, is crucial for their integration and success in the host society. Norms of family solidarity among minority populations, however, tend to differ from those regulating intergenerational support exchange among natives. Using original data collected in a city in Northeastern Italy via a semi-structured questionnaire featuring vignettes, we explore values and norms about parental financial support towards children among Chinese, Maghrebi and Filipino immigrants. The vignette analysed here contrasts the beneficiaries of support provided by parents to children (sons versus daughters) and the object of support (opening a new business versus pursuing higher education studies). Results point to a preference for supporting offspring - especially daughters - who want to invest in an educational career. This attitude is more widespread among Filipino and Chinese respondents than among Maghrebis. Daughters are favoured over sons among Filipinos, whereas the opposite holds for the other two groups. Supporting adult children's higher education is seen as an efficient investment strategy, reflecting a normative view of children's life courses.
\end{abstract}

Keywords: intergenerational relations, intergenerational transfers, immigrant, education, vignettes, Italy, China, Maghreb, Philippines

\section{Introduction}

Financial support given by parents to their children along their life course is an important factor affecting the latter's life chances and wellbeing. Previous research has consistently shown that, in Western European societies, parental help significantly influences children's educational attainment, occupation, home ownership, income and wealth (Ballarino and Bernardi 2016; Albertini \& Radl 2013; Kiernan and Mensah 2010; Wiborg and Møberg 2010). This is even more so for children of immigrant origin: intergenerational support is crucial for their socio-economic integration in the host society and for reducing inequalities in life chances, opportunities and wellbeing with respect to native children (McLanahan and Perchesky 2008; Rumbaut 1997; Waters 1997). Research findings also point to the fact that immigrant-origin children's intergenerational mobility - in terms of educational attainment and labour market success - may be significantly influenced by their ethnic environment through "ethnic capital" and "mobility ladders" (Borjas 1992; Portes and Zhou 1993).

Immigrant children's lower educational attainment and lower propensity to enrol in tertiary education, as compared to natives', have often been accounted for by referring to factors such as parents' lower human capital and social class, more fragile family structures, higher intergenerational conflict, stronger support obligations towards older generations. Moreover, empirical evidence collected in Western countries suggests that while foreign-origin students' educational disadvantages - socio-economic background being equal - rely more on "primary effects" - such as prior scholastic performances they enjoy positive "secondary effects" - i.e. parental support, encouragement in

\footnotetext{
${ }^{1}$ marco.albertini2@unibo.it; giancarlo.gasperoni@unibo.it; d.mantovani@unibo.it
} 
investing in educational careers and aspirations to pursue tertiary education (Kristen et al. 2008; Cebolla-Boado 2011; Jackson et al. 2012; for similar findings in Italy, see Ress and Azzolini 2014; Contini and Azzolini 2016).

In general, previous research on immigrant-origin children's disadvantages has focused on the role of families' socio-economic background and parents' human and cultural capital in order to explain educational differentials, devoting relatively scant attention to the relevance of varying cultural norms about intergenerational support (Dustman, Frattini and Lanzara 2012; Bohlmark 2008). Moreover, when comparing differences in actual transfer behaviour between native and immigrant population, sociological and demographic studies of intergenerational relations have often ignored the role of cultural norms regulating these relations; in most quantitative studies, observed differences are usually explained by a set of individual and household demographic and economic characteristics (Rapoport and Docquier 2006). Once these factors have been accounted for, the remaining variation associated with the status of (first or second generation $^{2}$ ) immigrant is often attributed to differences in cultural traits or norms regulating family solidarity that often not directly observed - i.e. included in survey micro-level data. Also, when explicitly addressing the role family solidarity norms play in shaping individuals' transfer behaviour, many studies have only focused on filial obligations towards elderly parents; norms regulating parental support for children are often neglected, again due to data availability constraints (Bordone and De Valk 2016, Schans and Komter 2010, Silverstein and Attias-Donfut 2010, De Valk and Schans 2008). This article aims to start filling this gap by analysing family norms among three different immigrant groups living in Italy, i.e. first and second generations from China, the Maghreb area and the Philippines. In particular, by using original data gathered via the use of vignettes and adopting a mixed-methods approach, we explore values and norms involving parental support obligations that shape respondents' preferences in terms of providing help to young adult offspring and prioritizing help toward their academic or working careers. It is worth noting that, although differences between the three abovementioned groups will be the main focus of the analysis, in interpreting the results we will be careful to de-essentialise membership to these groups. We cannot observe all of the relevant characteristics along which heterogeneity within the three groups may be structured (such as, for example, respondents' specific cultural backgrounds or legal status), but the analytical approach will take into consideration the methodological debate revolving around the concept of super-diversity (Vertovec 2007; Meissner and Vertovec 2015) and previous research documenting the role of super-diversity in shaping the assimilation and social mobility patterns of second-generation immigrants (e.g. Crul 2016; McGarrigle 2016). Consequently, we will assess not only differences between the three groups, but also differences associated with respondents' gender, age, age at arrival in Italy, educational level, employment status and position in the family generational lineage.

2 We adopt the following definitions of these terms in this study: first generations comprise individuals who have actually undertaken migration (i.e. non-Italians born abroad), whereas second generations refer to individuals born in the host country to two immigrant parents (i.e. born in Italy to non-Italian parents). 


\section{Intergenerational support and solidarity norms among immigrants}

Despite increased academic interest in patterns and factors affecting intergenerational solidarity and exchange of instrumental support in Europe (Albertini, Kohli and Vogel 2007), little attention has been paid to the specific configuration of these phenomena among immigrants, especially those from low-income countries. Existing literature clearly shows that families of immigrant origin face a dramatically different set of challenges and opportunities than native families, and that for many of them the intrinsic logic of intergenerational exchange of support and the cultural rules and traditions governing these exchanges differ from those observed among natives. Moreover, immigrants' transfer behaviour varies considerably according to country of destination, cultural background and country of origin (Attias-Donfut et al. 2012, Attias-Donfut and Wolff 2008, Baykara-Krumme 2008, De Valk and Schans 2008; Albertini et al. forthcoming).

Differences between native and minority populations in norms regulating transfer behaviour concern a variety of domains: rules regulating parents' and children's support obligations and the choice of strategies to be adopted; expectations about the support to be provided/received to/from the enlarged family network; norms regulating resource sharing between older and younger generations, sons and daughters, fathers and mothers; priorities attached to children's and parents' needs. Existing studies rarely observe these norms and assess their role. Thus, even when differing patterns of intergenerational support are observed between natives and immigrants, the question still holds: do these differences stem from specific sets of resources, needs and opportunities characterising immigrant families and their life courses, or do they - at least to some extent - reflect specific cultural preferences and expectations?

Family norms may not always translate into actual support behaviour, yet they are an excellent proxy of how families are supposed to work and of individuals' outlooks concerning the support available to or expected from them (Kang and Raffaelli 2016, Klein Ikkink, van Tilburg and Knipscheer 1999). In general, normative solidarity is a major dimension along which family solidarity is built and structured (Giarrusso et al. 2005, Bengtson and Roberts 1991).

\section{Support networks, transfer behaviour and family solidarity norms}

Immigrant families' support networks are often limited by structural constraints, particularly in terms of available resources and the families' geographical dispersion. As argued by Silverstein and Attias-Donfut (2010), transferring economic resources to other generations within the family might be especially difficult for immigrants: elderly members - left behind in the origin countries or first generation immigrants - are often not eligible for pensions or other public economic assistance, while younger members face high risks of unemployment or low income occupations and, therefore, have little resources available to save or transfer to other family members (Treas and Mazumdar 2004). Moreover, especially for first generation immigrants, belonging to transnational families might often imply that family members still living in the country of origin heavily rely on remittances, thus limiting the potential for financial transfers to younger family members in the destination country. Even though financial transfers may have a special relevance for transnational families, they also place importance on providing/receiving 
care and emotional support (Boccagni 2015, Baldassar 2007, Treas and Mazumdar 2004, Baldok 2000) $)^{3}$.

A number of scholars have stressed the fact that kin networks are particularly relevant in societies from which a large number of immigrants living in Western Europe and North American originate. Such networks are often crucial in guaranteeing social protection to ageing individuals (Foner 1984), but are clearly relevant for other family members as well (Agree, Biddlecom and Valente 2005; Borjas 1992; Portes and Zhou 1993). The "model of family change", proposed by Kagitcibasi, suggests that most immigrants moving from low-income countries to Europe and North America have to deal with the difficult transition from a collectivistic to an individualistic culture. In the former, full (i.e., emotional and practical) interdependence between family members is highly valued, whereas individualistic societies tend to stress independence and selfreliance, fostering emotionally interdependent - but practically independent - family relationships (Kagitcibasi, Atca and Diri 2010, Kagitcibasi and Atca 2005). Empirical research on the outcomes of this adaptation process provides mixed findings: some studies show a shift from collectivistic to individualistic values and expectations (e.g. Ajrouch 2005) and suggest that faster adaptation by second generations produces increased generational conflict with older family members (Zhou 2009, Hwang, Wood and Fujimoto 2010, Silverstein and Chen 1999); other studies, such as that of BaykaraKrumme and Fokkema in this special issue (see also Bean and Tienda 1987, Cela and Fokkema 2016, Portes and Rumbaut 2011), show that cohesiveness and material solidarity tend to be stronger among those who migrated than among stayers in origin countries, and that the migration process - and the correlated difficulties and life experiences - leads to a strengthening of collectivistic norms and behaviour. This second group of studies is coherent with research showing that immigrant adult children are characterized, vis-à-vis native peers, by more robust feelings of filial obligation and indebtedness towards parents. Such feelings are more pronounced in less educated families and among those who have migrated quite recently (Kang and Raffaelli 2016, Schans and Komter 2010, de Valk and Schans 2008, Ajrouch 2007, Burr and Mutchler 1999) and mirrored in the high expectations of support expressed by elderly immigrant parents, similar to those of stayer parents (Trieu 2016, Nauck and Suckow 2008).

Although findings from comparative research on immigrants' transfer behaviour are often mixed, numerous empirical studies highlight some uniform results. In particular, it is often found that, unlike what is observed among natives, in immigrant groups: (i) financial support flows mainly upward along the generational lineage within the family, in that the likelihood of making a transfer to children is lower than that of giving to parents; (ii) the exchange of economic support - especially under the form of informal loans - is more likely to involve individuals outside the nuclear family, i.e. enlargedfamily members and non-relatives; (iii) the amount of social support provided by first generations to their parents is, on average, lower than levels registered for native population - mainly due to geographical distance. An opposite finding, i.e. more social support with respect to natives, is found among immigrants whose parents have also moved to the destination country. In such families (iv) parent-adult children co-residence is more common; (v) despite, in some ethnic groups, parents' high expectations towards children's educational achievement, siblings who study are not more likely than others to

3 Given our specific research interest and the available data, in this article we will not address intergenerational transfers within transnational families, which however is a relevant topic that has received considerable attention from scholars of migration (e.g. Sana 2005, Baldassar 2007b, Rooyakers, De Valk and Merz 2016, King et al. 2014, de Bruine et al. 2013). 
receive financial transfers from parents. These common patterns vary in their strength and significance depending on immigrant groups' specific origins and destinations, although of course they may do so along other dimensions such as social class, educational level, gender, age, etc. (Silverstein and Attias-Donfut 2010, Schans and Komter 2010, Attias-Donfut and Wolff 2009, 2008, Bjönberg and Ekbrand 2008, Baykara-Krumme 2008, de Valk and Schans 2008, Wolff, Spilerman and Attias-Donfut 2007, Aldous 2006, Lowenstein 2002, Louie 2001, Kritz 2000).

\section{Intergenerational relations among Maghrebis, Filipinos and Chinese}

There are numerous studies of family solidarity norms and intergenerational exchange of support in the three groups considered here. These studies analyse both family relations in the countries of origin and exchange of support among those who have migrated. In this section we briefly review some of the most important findings drawn from this body of research.

\section{Maghrebis}

The role of extended family as the main source of support for its members emerges quite clearly both from studies on Maghrebi societies and analyses of Moroccan, Tunisian and Algerian immigrants in Europe and the U.S. In this group, family solidarity is based on bonds connecting the male members sharing the same paternal lineage: men are expected to provide financial resources and women to uphold the collective interests of the kin group (Charrad 2001). Intergenerational co-residence is a frequently adopted strategy to help family members, in part due to the fact that in the three countries public support systems are underdeveloped (Yount and Sibai 2009).

Values and norms of family solidarity among Maghrebi immigrants are strong, particularly among those who have arrived recently in the host country and report affiliation to Islam (Merz et al. 2009). Coherently with these norms, Maghrebis tend to provide social support to their family members more frequently than both natives and other minority groups and are more likely to live in multigenerational households (Schans and Komter 2010). Similarly to other minority groups, migrants from Maghreb are less likely than natives to provide financial transfers to their children. However, unlike other groups, when they do so they are more likely to support sons than daughters, thus maintaining gender patterns from their origin country (Silverstein and Attiaas-Donfut 2010; Attias-Donfut and Wolff 2009; Wolff, Spilerman and Attias-Donfut 2007).

\section{Filipinos}

As in Maghrebi countries, in the Philippines intergenerational co-residence is a common strategy for coping with the care and economic needs of family members and insufficient public provision. Financial transfers from adult children to elderly parents are particularly relevant, and most parents rely on such help as the main source of income in later life (Ofstedal, Reidy, Knodel 2003; Hermalin 2002). Various studies have pointed out that gender biases in transfer behaviour of Filipino families are negligible - for instance, elderly parents often rotate between different children's households without any gender preference (Agree, Biddlecom and Valente 2005, Natividad and Cruz 1997, Ofstedal, Knodel and Chayovan 1999, Asis and Domingo 1995). An exception to this pattern is documented by Quisumbing's study (1994) on transfers and inheritances in five Philippine rice villages: she found that daughters tend to receive less education, land and inheritance and are compensated with non-land assets. 
Research on Filipino immigrants has found that they are characterised by very strong values and expectations with reference to intergenerational support, especially as regards children's obligation to support elderly parents. Gender cleavages in support obligations and behaviour are absent or much less relevant among Filipinos than among other immigrant groups. Interestingly, stronger attitudes about family solidarity are correlated with stronger academic motivation but not with educational achievement of children (Treas and Mazumdar 2004, Fuligni, Tseng and Lam1999).

\section{Chinese}

In recent decades literature on intergenerational relations in Chinese families has flourished, with special attention being paid to both internal and international migrants. It has often been suggested that traditional traits, such as Confucianism, emphasize family solidarity and commitment. Coherently with these traditions, and reflecting the weakness of the public support system for the elderly, Chinese society is characterized by strong social norms concerning filial obligation to provide help to elderly parents; moreover, this support is the most relevant source of old age security in China, where, in general, a collectivistic culture prevails (Guo, Chi and Silverstein 2012, Chen and Silverstein 2000, Zimmer and Kwong 2003, Thang 2010, Peng and Wong 2010, Sun 2002). Intergenerational co-residence is also widespread, particularly with married sons (Ofstedal, Knodel and Chayovan 1999).

Despite the resilience of such values (Forrest Zhang 2004), massive internal and international migration is challenging traditional norms of intergenerational support (Silverstein 2006). While norms of family support are relatively strong among Chinese immigrants (Fuligni, Tseng and Lam 1999), elderly Chinese international migrants report important shifts in their expectations about filial support, towards an increase in their reliance on the health care system, friends and neighbours (Pang et al. 2003). This adaptation is likely to reduce the burden falling on Chinese second generations, thus liberating resources that can be transferred to younger generations. A further important finding is the increasing importance attached by Chinese parents - both living in urban China and abroad - to investment in their offspring's educational careers (Forrest Zhang 2004, Sue and Okazaki 1990, Kao and Thompson 2003, Louie 2001).

\section{Method}

\section{Data collection}

The data utilized in this article is drawn from a survey conducted between November 2014 and April 2015. Our sample comprises 347 individuals hailing (or born to parents) from three distinct areas, featuring relatively heterogeneous cultural traits: the Maghreb (Morocco, Tunisia and Algeria), the Philippines, and China. Respondents were recruited via a snowball technique among adults residing in the province of Bologna (in Northeastern Italy); once a respondent had participated in the study, other family members were ineligible for recruitment.

The immigrant population in Italy is unequally distributed across its regions and more highly concentrated in the North. Maghrebis - especially Moroccans - are one of 
the major immigrant groups in the Bologna province ${ }^{4}$ and comprise one of the earliest (hence deeply-rooted) migrant flows towards Italy. Immigrants from the Philippines are also one the most populous and early non-native communities in Bologna, dating back to the early 1980s; they continue to be employed, typically, as domestic workers ${ }^{5}$. Finally, Chinese-origin migrants feature a rapid numerical growth over the last 20 years, a strong entrepreneurial aptitude ${ }^{6}$ (Ceccagno 2003) and a settlement behaviour featuring a high degree of geographic concentration (Bergamaschi 2011).

Interviews with Maghrebis and Filippinos were conducted, mostly in Italian, by 15 trained interviewers. Only one interviewer was able to speak Arabic, a few were fluent in French and Spanish, and all of them could speak English. A trained Chinese interviewer was employed to conduct the survey among immigrants from her country; familiar with the community, she conducted most of her interviews in Chinese. All interviewers attended training meetings (held by the authors) informing them about the study's goals. Simulated interviews were conducted and discussed collectively. Throughout interviews' collection, one of the authors systematically assisted interviewers in recruiting respondents and by checking data reliability. The administered questionnaire included, besides a central section comprising a set of vignettes aiming at capturing norms and values on family intergenerational solidarity, an initial and a final section with closedended items regarding individuals' socio-demographic characteristics and ties with family members.

\section{Investigating norms on economic solidarity towards children using vignettes}

The exploration of practical and financial support among migrant families raises problems that typically plague the study of norms, values and beliefs. Since norms and values are implicitly interiorized through socialization (Mead 1934; Scott 1971), pertinent outlooks and actions may be difficult to access. Moreover, the investigation of perceived moral and material commitments and obligations among immigrants is even more arduous, as they may not share the researchers' norms and values. The standard data collection techniques used in the initial and final sections of the questionnaire are obviously less effective for the exploration of such topics.

Hence, the focus of this paper is based on data collected via so-called "vignettes": "short stories about hypothetical characters in specified circumstances, to whose situation the interviewee is invited to respond" (Finch 1987, 105). A major advantage of this technique is its non-directive nature, providing the opportunity to collect reliable data concerning beliefs and norms underpinning family obligations. Respondents are not asked to state what they personally would do in a given realistic situation, but rather what the characters depicted in the vignette ought to do. Due to the distance it places between interviewees and characters, the impersonal stimulus reduces social desirability bias and encourages less guarded reactions and a more spontaneous revelation of value orientations. Although vignettes represent hypothetical scenarios, they aspire to reproduce realistic situations that respondents can easily recognize and to which they can

4 In the 2014-2015 period, $15.2 \%$ of 117,122 non-Italians in Bologna came from Maghreb region, and almost eight out of ten Maghrebis (78.7\%) were from Morocco. Moroccans were the largest non-native group in the province of Bologna up to 2008, when they were replaced by Romanians.

5 Accounting for 5.3\% of the entire non-Italian population, Filipinos were the seventh largest immigrant group in the province of Bologna in 2015.

6 In 2015, 4.8\% of non-Italians in Bologna were Chinese. 
relate, about which they can express a grounded opinion and perhaps reflect their cultural identity, via answers to close-ended questions or more narrative-based responses (we use both types of information in our analysis).

The vignette at the centre of our analysis aims to understand norms regulating parents' financial transfer behaviour towards their children. The vignette describes a situation in which a couple of immigrant parents are confronted with the competing demands for financial help from their two children. Both children are unmarried and still live with their parents: the older one (age 22) has lost his/her job and wants to start a small business (a shop); the younger one (age 18, quite good at school) would like to pursue an academic career in an Italian university far from the place of residence. Finally, the vignette specifies that the parents do not have sufficient resources to support both children's needs. Respondents were then asked an open-ended question: "What should the parents do?". The intention is to identify criteria used by respondents and the underlying values and norms that guide respondents in identifying how the parents should behave, to which child they should give priority and why (without obliging respondents to feel that they personally, in a similar situation, must behave in any specific way) ${ }^{7}$.

The vignette was formulated in four different versions, following a factorial design, differentiating children's gender according to the type of need (see table 1). The specific version administered to a given respondent was determined randomly. Interviewers were trained to discourage respondents from giving non-committal responses ("the parents ought to help both children") and underline, if necessary, that parents' financial resources were categorically insufficient to meet both children's needs. Interviewers were also instructed to probe the reasons underlying responses ("Why do you consider this solution the best?"). Also, each version of the vignette is further differentiated: the names of all characters identify them as members of the ethnic group to which the respondent also belongs (so, strictly speaking, 12 distinct versions of the vignette were used: four for each of three migrant groups).

[table 1 about here]

The responses to the vignette have been coded using a two-step procedure: in the first step we have identified who, between the two siblings, the respondent thinks should get economic support from his/her parents. In the second step, we have codified the reasons which have been given by the respondent when asked why s/he thinks providing support to the identified beneficiary is the appropriate solution. In the second step we allowed for multiple coding; i.e. in a number of cases the respondent highlighted more than one reason to support his/her choice.

7 The text of one version of the vignette is as follows (country of origin and children's names are omitted): "A young immigrant couple from ... has two children: an 18-year-old male and a 22-year-old female. Neither child is married, and both still live at home with their parents. The younger son has just finished secondary school, is a very good student and would like to study at university in Milan. The elder daughter, after secondary school, worked for a few years as a store clerk and is now without a job due to the economic crisis; now she would like to open a small shop. Unfortunately both children need financial help from their parents in order to implement their projects. Their parents, however, do not have enough money to help both. What should the parents do?". 


\section{The sample}

Our sampling strategy obviously has no probability basis nor any claim to representativeness; yet a comparison of the socio-demographic profiles of sample subgroups and the corresponding immigrant-origin communities in the Emilia-Romagna region is revealing (table 2). Respondents are, roughly, equally distributed between males and females and relatively young; in the Filipino subsample females are over-represented, and the Chinese subsample is younger than the reference population. Distribution by country of birth reflects the strong majority status of Moroccans among Maghrebis, who also feature a small "second-generation" group of Italian-born respondents (9\%). Most Filipino and Chinese respondents were born in their respective reference countries, although again the incidence of second generations is not negligible - respectively 15 and $6 \%$. These findings suggest that the three groups are well-settled in the receiving society. Approximately half of Maghrebi and Chinese respondents are single, whereas a majority of Filipinos are or have been married. Divorcees and widow(er)s are absent in the Chinese subgroup.

Discrepancies between subsamples and reference communities are more conspicuous as regards level of education and employment status. Respondents are more educated than their fellow community members, albeit less markedly so among Chinese; this imbalance is probably due to the relatively high incidence of students in the sample (one-fifth overall) and perhaps to the fact that all interviews with Chinese-origin respondents were carried out in Chinese, whereas most of interviews with Maghrebis and Filipinos were conducted in Italian and thus excluded, perhaps, less educated people. The employed and the unemployed are, respectively, under- and over-represented in the Maghrebi and Filipino subgroups, whereas the two groups are respectively over- and under-represented among Chinese respondents.

[table 2 about here]

\section{Results}

\section{Whom should parents support?}

As explained above, the vignette analysed here requires the respondents to report how, in their view, parents of their same ethnic group should behave when confronted with the competing demands of financial support from two children: the younger child would like to further his/her academic career by enrolling in a university degree programme (far from home), whereas the older child is seeking help to start a small business.

The majority of respondents $(57 \%)$ thinks that parents should support the child who wants to enrol in university studies; a third are in favour of helping the older child, and, finally, less than $10 \%$ do not express any specific preference - insisting that either both or none of the children should receive financial support (table 3). There is relatively little variation with respect to this pattern across the three ethnic groups. Chinese respondents are the most likely (65\%) to prioritize support to the child who wants to study, whereas Maghrebis are the least likely (51\%).

The response distribution seems to be largely unaffected by the specific version of the vignette utilized. The only partial exception involves the FF vignette (in which both children are daughters), which generates a higher propensity to support both children and a weaker preference for provision of support solely to the business-minded daughter. 
[table 3 about here]

When we restrict the analyses to the two versions of the vignette in which respondents were confronted with a situation in which the children are of different genders (MF and FM), the Chinese express a higher propensity to favour the son (58\%), whereas Filipino immigrants tend to prefer daughters (65\%). Respondents from the Maghreb countries are equally likely to opt for sons or daughters (42 versus 43\%) and more likely than in the other two groups to feel that both children should be supported $(12 \%)$. These findings should be treated with particular caution, for they refer to a subset of all cases.

The between-group variations reported above might reflect differing values and norms characterising the three ethnic groups or - to some extent - originate from the latter's dissimilar socio-economic composition. Therefore, it is worth exploring whether these differences persist once we control for individuals' socio-economic characteristics (gender of respondent, age, age at arrival in Italy, educational level, employment status, generational position). This is done via a set of multivariate logistic regression models attempting to account for two distinct dependent variables: a variable that takes the value of 1 when the respondent states that parents should prioritize financial support to the child who wants to invest in his/her academic career (and 0 when any other response was given: models A1, A2 and A3); a variable that takes the value of 1 when the respondent reacting to the FM or MF version of the vignette - states that parents should prioritize financial support to the daughter instead of the son (and 0 when any other response was given: models B1, B2 and B3). Results are reported in table $4^{8}$ : Models A1 and B1 include only immigrant group and vignette version as explanatory variables; Models A2 and B2 include, besides the vignette version, an array of socio-demographic characteristics, but not immigrant group; Models A3 and B3 are more complete models, comprising all the variables included in one of the previous models.

Model A1 confirms that Filipinos and, especially, Chinese immigrants are more likely to recommend support for the child interested in further education, and that this preference is slightly stronger if that child is a daughter. Model A2 shows that factors that are negatively associated with prioritizing support to the youngest child (i.e. interested in furthering education) are: initial arrival in Italy at school age (i.e. between 6 and 17), a medium-high educational level, older current age, being a student or in another nonworking condition, belonging to a "pivot" generation (i.e. being both a parent and a child). The negative effect of arrival at school age and being a student are perhaps surprising, since one could have reasonably expected respondents with these characteristics to have a greater chance of being successfully integrated in the destination country and having experienced tertiary education. Perhaps respondents' personal experiences belie such expectations, in that they have developed a negative view of their studies in Italy (or have no such experience) - but unfortunately our dataset contains no information on this point. Interviews hint at the possibility that some respondents feel that children enrolled in a university have a duty to limit their parents' economic burden by studying in the same city where their parents live (and thus continuing to live under the same roof) and/or simultaneously working part-time. Including respondents' socio-economic characteristics in the analysis leads to a stronger explanatory power. Model A3 confirms

8 Since our sample is not representative of the migrant population, the results cannot be generalised to individuals other than the ones we interviewed. For this reason we have omitted significance statistics from table 4 . 
that a large part of the initial difference (in Model A1) between the Filipino and Chinese respondents is due to compositional effects. Yet, even after controlling for socioeconomic characteristics and vignette version, respondents from the Maghreb remain the least likely to prioritize university enrolment over opening a shop (the difference with Chinese respondents is about 10 percentage points, as seen in the top half of figure 1 reporting predicted probabilities of Model A3). At the same time, this model also suggest that other individual's characteristics - such as age at arrival and employment status might be more relevant explanatory factors than the ethnic group. Finally it worth noting that the belief that parents should make a financial transfer to support children's academic career is stronger when the beneficiary is a daughter'.

Regression models (B1, B2 and B3) involving only those vignettes in which the two siblings' genders differ show that Filipino respondents are more likely to feel that financial support should be given to the daughter, whereas Chinese and Maghrebi respondents tend to prioritize support for the son (table 4; figure 1: bottom half reporting predicted probabilities of Model B3). Once again, it is worth noting that some sociodemographic characteristics appear to be more relevant than immigrant group: heterogeneity connected with respondents' gender, generational position, age at migration and employment status is larger than that observed between groups (figure 1). In particular, being a man, having arrived in Italy before the age of 6 , having completed tertiary education and being a student are positively associated with preferring the daughter as the beneficiary of parental support. Also, when the vignette identifies the child who wishes to continue studying as the daughter, the likelihood of prioritizing support to the daughter further increases.

[table 4 about here]

[figure 1 about here]

\section{Why should parents support the educational career of the child?}

Analysis of the answers to open-ended questions concerning the reasons underlying respondents' orientations allows us to explore the values and norms that underpin immigrants views about parents' support obligations towards adult children.

Here in particular we focus on the motivations provided to support the idea that parents should prioritize the educational careers of one of their children. The great majority of responses can be grouped into three broad categories: first, the importance of investing in education - per se or because of the expected economic and occupational returns; second, the adequacy of the solution preferred with respect to children's life courses and the optimal timing for studying versus working; third, the availability of alternative solutions to the older child (table 5). Many responses refer to multiple motivations.

The majority of those who prioritize support to the younger child feel that this is coherent with a view of education as an investment in his/her future occupational career, and consequently a benefit for the entire household's economic well-being.

9 Additional analyses including the interaction between vignette version and immigrant group suggest that this effect -i.e. a preference for education of daughters - is more pronounced for Filipino and less so for Chinese respondents, with the Maghrebis falling in between. 
They should help the daughter who studies, because later on this sacrifice could mean advantages in finding a good, paying job and so repay the effort. Also, by achieving a better future and more job opportunities, one day she herself could be able to help them should they have problems.

[male, age 79, born in Morocco, arrived at age 44, retired ex-butcher, FM vignette]

Because investing in schooling makes more sense than investing in a shop; it's less risky and she would have a better future.

[male, age 25, born in China, arrived at age 24, owner of consultancy firm, FF vignette]

Studying also means intending to find a good job and later a good wife.

[male, age 19, born in Morocco, arrived at age 18, unemployed, MF vignette]

The couple of parents should help their daughter Michelle who wants to study, because after earning her degree she can find a good job and help her brother Ryan open a shop. [male, age 52, born in the Philippines, arrived at age 27, house servant, FM vignette]

So some stated reasons justifying the transfer of economic resources to children consider the long-term consequences of parents' support. Investing in the educational career of a child appears to be a more promising and secure strategy than investing in the opening of a small shop.

A second important norm emerging from our data is related to children's life courses and the "correct" timing of studying with regard to working. While starting a small business is something that is seen as being possible along the entire adult life of a child, enrolling in a university to study is seen as appropriate only at the early stages of adult life. In other words, getting a university degree is an opportunity that will not arise again as the child ages and enters the paid labour market.

They should help the daughter that wants to study because studying is more important. The other daughter can take out a bank loan for the shop; since she has already worked, she has experience and has a better chance of finding another job. This is the best solution because I think studying is more important: as long as the daughter wants to study and is young, it's fair that she continue. Once you stop you no longer feel like it; it's difficult to start studying again after a lengthy pause. I, for example, attend classes in the evening and in the meantime work with my father in our cleaning business. It's hard to study and work at the same time.

[male, 23 years old, born in Philippines, arrived at age 6, owner of cleaning company, FF vignette]

The parents should help Elias because it's important to provide children to study. You can study only when you're young.

[female, age 42, born in Morocco, arrived at age 24, caregiver, MF vignette]

Because if he loses this opportunity he may not have other shots at studying. It's more urgent, whereas she can always open a business a couple of years later. For now she can look for another job and when she has more money she can open a shop.

[female, age 23, born in China, arrived at age 13, hair dresser, MF vignette]

As reported in table 5, survey participants justify their responses in many ways. A particularly interesting one, mentioned by just 9 respondents, has to do with the prestige 
associated with earning a tertiary degree. As mentioned above, parents' aspirations concerning their children's educational career in the host society are an important factor accounting for their academic achievement. Notably, the respondents that explicitly mention this aspect are all Maghrebis.

If they must choose one of the two children, then the parents should let their daughter study. The son is a man and so can make do. The daughter may find it more difficult to find a job... plus, the degree is a source of prestige for the family and could lead to more social mobility.

[male, age 28, born in Tunisia, arrived at age 1, student, FM vignette]

They must help the daughter who is studying. By studying she can get a better job and the parents can take pride in her educational career.

[female, age 34, born in Morocco, arrived at age 19, caregiver and house servant, FF vignette]

[table 5 about here]

\section{Conclusions}

Parental support is crucial for the socio-economic integration and success of immigrants' children in European societies. This support is especially relevant when children of immigrant origin consider the possibility of enrolling in a university and thus investing in their educational career. Although previous research has consistently documented that, among minority populations, parents have high expectations about their children's educational achievement, children of immigrant origin have a lower probability than their native peers to enrol and complete tertiary education. In Italy, 51\% of Italian citizens completing higher secondary education enrol in university programmes, whereas among non-Italian citizens only 35\% do so (MIUR 2013).

In general, our findings help shed light on family solidarity norms among three specific immigrant groups and contribute to explaining immigrant-origin children's disadvantage in terms of enrolling in a university vis-à-vis their native peers. More specifically, in our study we have found that in each of the three immigrant groups the majority of respondents share the view that parents should prioritize financial support to a child who wants to engage in higher education versus a child who needs assistance to start a small shop. This reflects previous research documenting "immigrant optimism" and reporting positive secondary effects among immigrant families, versus adverse primary effects (Cebolla-Boado 2011; Kristen et al. 2008; Contini and Azzolini 2016). Also, investing in the academic career of a child is seen as particularly appropriate when the beneficiary is a daughter rather than a son.

However, there is considerable variation among the three groups. First, both Filipino and Chinese respondents are more likely than individuals from the Maghreb to prioritize support to the child who wants to study in a university. Second, when children are of different genders, priority to daughters is widespread among the Filipinos, whereas preference for sons is more frequent among the other two groups. Analysis also reveals that the main reason why respondents think parents should prioritize children's education over work is that the former is perceived as a more advantageous investment strategy, especially in terms of occupational returns and also - to some extent - social prestige accruing to the family. These motivations appear to be particularly widespread among 
both Maghrebi and Filipino respondents, whereas among respondents of Chinese origin motives connected with optimal timing for higher education are more common. Nevertheless, between-groups differences should not be over-emphasized. Consistently with previous literature stressing (super-)diversity among immigrants', our analyses point to significant within-group heterogeneity. In particular, age at migration and employment status seem to play a relatively greater role than ethnic origin in shaping respondents attitudes towards prioritizing support for children who wish to study and for daughters over, respectively, business-minded children and sons. Support for children's academic aspirations is also stronger among less educated respondents. Gender biases in support norms are also appreciably connected with respondents' gender and position in the family generational lineage.

\section{References}

Agree, E.M., A.E. Biddlecom and T.W. Valente. 2005. "Intergenerational transfers of resources between older persons and extended kin in Taiwan and the Philippines." Population Studies 59(2): 181-195.

Ajrouch, K.J. 2005. "Arab-American immigrant elders' views about social support." Ageing \& Society 25(5): 655-673.

Ajrouch, K.J. 2007. "Health disparities and Arab-American elders: Does intergenerational support buffer the inequality-health link?" Journal of Social Issues 63(4): 745-758.

Albertini M, G. Gasperoni and D. Matonvani (forthcoming) "Intergenerational relations among immigrants in Europe: the role of ethnic differences, migration and acculturation." Journal of Ethnic and Migration Studies.

Albertini, M., M. Kohli and C. Vogel. 2007. "Intergenerational transfers of time and money in European families: common patterns - different regimes?" Journal of European Social Policy 17(4): 319-334.

Albertini, M. and J. Radl. 2013. "Intergenerational transfers and social class: Inter-vivos transfers as means of status reproduction?" Acta Sociologica 55(2): 107-123.

Aldous, J. 2006. "Family, ethnicity, and immigrant youths' educational achievements." Journal of Family Issues 27(12): 1633-1667.

Asis, M.M.B. and L.J. Domingo. 1995. "Living arrangements and the flow of support between generations in the Philippines." Journal of Cross-Cultural Gerontology 10: 21-51.

Attias-Donfut, C. J. Cook, J. Hoffman and L. Waite. 2012. Citizenship, belonging and intergenerational relations in African migration. Basingstoke: Palgrave Macmillan.

Attias-Donfut, C. and F.-C. Wolff. 2008. "Patterns of intergenerational transfers among immigrants in France: a comparative perspective." In Families, Ageing and Social Policy, edited by C. Saraceno, 259-284. Cheltenham, Edward Elgar.

Attias-Donfut, C. and F.-C. Wolff. 2009. Les destin des enfants d'immigrés. Un désenchaînement des generations. Paris: Stock.

Baldassar, L. 2007. "Transnational families and aged care: the mobility of care and the migrancy of ageing." Journal of Ethnic and Migration Studies 33(2): 275-297.

Baldassar, L. 2007b. "Transnational families and the provision of moral and emotional support: The relationship between truth and distance." Identities 14(4): 385-409.

Baldock, C.V. 2000. "Migrants and their parents. Caregiving from distance." Journal of Family Issues 21(2): 205-224. 
Ballarino, G. and F. Bernardi. 2016. "The intergenerational transmission of inequality and education in fourteen countries: a comparison." In Education, Occupation and Social Origin. A comparative analysis of the transmission of socio-economic inequalities, edited by G. Ballarino and F. Bernardi, 255-281. Cheltenham: Edwar Elgar.

Baykara-Krumme, H. 2008. "Reliable bonds? A comparative perspective of intergenerational support patterns among migrant families in Germany." In Families, Ageing and Social Policy, edited by C. Saraceno, 285-311. Cheltenham, Edward Elgar.

Baykara-Krumme, H. and T. Fokkema. 2017. "The impact of migration on intergenerational solidarity types." Journal of Ethnic and Migration Studies.

Bean, F. and M. Tienda. 1987. The Hispanic population of the U.S.. New York: Russel Sage.

Bengtson, V.L. and R.E.L. Roberts. 1991. "Intergenerational solidarity in aging families: An example of formal theory construction." Journal of Marriage and Family 53(4): 856-870.

Bergamaschi, M. 2012. "Distribuzione territoriale e modelli insediativi della popolazione straniera a Bologna." Sociologia urbana e rurale 99: 117-134.

Bjönberg, U. and H. Ekbrand. 2008. "Intergenerational solidarity and social structures in Sweden: class, ethnicity and gender in public and private support patterns." In Families, Ageing and Social Policy, edited by C. Saraceno, 236-258. Cheltenham, Edward Elgar.

Boccagni, P. 2015. "Burden, blessing or both? On the mixed role of transnational ties in migrant informal social support." International Sociology 30(3): 250-268.

Böhlmark, A. 2008. "Age at immigration and school performance: A siblings analysis using Swedish register data." Labour Economics 15(6): 1366-1387.

Bordone, V. and H.A.G. De Valk. 2016. "Intergenerational support among immigrant families in Europe. European Journal of Ageing 13(3): 259-270.

Borjas G. 1992. Ethnic Capital and Intergenerational Mobility, Quarterly Journal of Economics, vol. 107, n. 1, pp. 123-150.

Burr, J. and J.E. Mutchler. 1999. "Race, and ethnic variation in norms of filial responsibility among older persons." Journal of Marriage and Family 61: 674-687.

Ceccagno, A. 2003. "New Chinese Migrants in Italy." International Migration 41 (3): 187-213.

Cebolla-Boado, H. 2011. "Primary and secondary effects in the explanation of disadvantage in education: the children of immigrant families in France." British Journal of Sociology of Education 32(3): 407-430.

Cela, E. and T. Fokkema. 2016. "Being Lonely Later in Life: A Qualitative Study among Albanians and Moroccans in Italy." Ageing and Society. doi: 10.1017/S0144686X16000209.

Charrad M.M. 2001. States and women's rights: The making of postcolonial Tunisia, Algeria, and Morocco. Berkeley: University of California Press.

Chen, X. and M. Silverstein. 2000. "Intergenerational social support and the psychological well-being of older parents in China." Research on Aging 22(1): 4365.

De Bruine, E., M. Hordijk, C. Tamagno and Y. Sánchez Arimborgo. 2013. "Living between multiple sites: Transnational family relations form the perspective of elderly non-migrants in Junín, Peru.” Journal of Ethnic and Migration Studies 39(2): 483500. 
Crul, M. 2016. Super-diversity vs. assimilation: how complex diversity in majorityminority cities challenges the assumption of assimilation. Journal of Ethnic and Migrations Studies, 42(1): 54-68.

De Valk, H.A.G. and D. Schans. 2008. "“They ought to do this for their parents': Perceptions of filial obligations among immigrant and Dutch older people." Ageing \& Society 28(1): 44-69.

Dustmann, C., T. Frattini and G. Lanzara. 2012. "Educational achievement of secondgeneration immigrants: an international comparison." Economic Policy 27(69): 143185.

Finch, J. 1987. “The Vignette Technique in Survey Research.” Sociology 21 (1): 105114.

Foner, N. 1984. Ages in conflict: A cross-cultural perspective on inequality between old and young. New York: Columbia University Press.

Foner, N. 1997. "The Immigrant Family: Cultural Legacies and Cultural Change." International Migration Review 31 (4): 961-974.

Forrest Zhang, Q. 2004. "Economic transition and new patterns of paren-adult child coresidence in urban China." Journal of Marriage and Family 66(5): 1231-1245.

Fuligni, A.J., V. Tseng and M. Lam. 1999. "Attitudes toward family obligations among adolescents with Asian, Latin American, and European Backgrounds." Child Development 70(4): 1030-1044.

Giarrusso, R., M. Silverstein, D. Gans and V.L: Bengtson. 2005. "Aging parents and adult children: New perspectives on intergenerational relationsips." In Cambridge Handbook of Aging, edited by M. Johnson M., V.L. Bengtson, P.G. Coleman, T. Kirkwood, 413-421. Cambridge: Cambridge University Press.

Guo, M., I. Chi and M. Silverstein. 2012. "The structure of intergenerational relations in rural China: A latent class analysis." Journal of Marriage and Family 74: 1114-1128.

Hermalin, A.I. (editor) 2002. The well-being of the elderly in Asia. A four-country comparative study. Ann Arbor, MI: The University of Michigan Press.

Hwang, W-C., J. Wood and K. Fuijmoto. 2010. "Acculturative family distancing (AFD) and depression in Chinese American families." Journal of Consulting and Clinical Psychology, 78(5): 655-667.

Jackson, M. J.O. Jonsson and F. Rudolphi. 2012. "Ethnic inequality in choice-drive education systems: A longitudinal study of performance and choice in England and Sweden." Sociology of Education, 85(2): 158-178.

Kagitcibasi, Ç. and B. Ataca. 2005. "Value of Children and Family Change: A ThreeDecade Portrait From Turkey." Applied Psychology: An International Review 54 (3): 317-337.

Kagitcibasi, C., B. Ataca and A. Diri. 2010. "Intergenerational Relationships in the Family: Ethnic, Socioeconomic, and Country Variations in Germany, Israel, Palestine, and Turkey." Journal of Cross-Cultural Psychology 41 (5-6): 652-670.

Kang, H. and M Raffaelli. 2016. "Personalizing immigrant sacrifices. Internalization of sense of indebtedness toward parents among Korean American young adults." Journal of Family Issues 37(10): 1331-1354.

Kao, G. and J.S. Thompson. 2003. "Racial and ethnic stratification in educational achievement and attainment." Annual Review of Sociology 29: 417-442.

Kiernan, K.E. and F. Mensah. 2010. "Poverty, family resources and childrn's early educational attainment: the mediating role of parenting." British Educational Research Journal 37(2): 317-336. 
King, R., E. Cela, T. Fokkema, J. Vullnetari. 2014. "The migration and well-being of the zero generation: transgenerational care, grandparenting, and loneliness amongst Albanian older people." Population, Space and Place 20(8): 728-738.

Klein Ikkink, K., T. van Tilburg and C.P.M. Knipscheer 1999. "Perceived instrumental support exchanges in relationships between elderly parents and their adult children: normative and structural explanations." Journal of Marriage and Family 61(4): 831844.

Kritz, M.M., D.T. Gurak and L. Chen. 2000. "Elderly immigrants: their composition and living arrangements." The Journal of Sociology and Social Welfare 27(1): 85-114.

Louie, V. 2001. "Aspirations and investments. The role of social class in the educational experiences of 1.5 and second generation Chinese Americans." Harvard Educational Review 71(3): 438-474.

Lowenstein, A. 2002. "Solidarity and conflicts in co-residence of three-generational immigrant families from the former Soviet Union." Journal of Aging Studies 16(3): 221-241.

McGarrigle, J. 2016. Islam in urban spaces: The residential incorporation and choices of Muslims in Lisbon. Journal of Ethnic and Migration Studies, 42(3): 437-457.

McLanahan, S. and C. Percheski. 2008 "Family structure and the reproduction of inequalities" Annual Review of Sociology 34: 427-449.

Mead, G. H. 1934. Mind, Self, and Society. Chicago: University of Chicago Press.

Meissner F. and S. Vertovec 2015. Comparing super diversity, Ethnic and Racial Studies, 38(4): 541-555.

Merz, E.M., E. Ozeke-Kocabas, F.J. Oort and C. Schuengel. 2009. "Intergenerational family solidarity: value differences between immigrant groups and generations." Journal of Family Psychology 23(3): 291-300.

MiUR 2013. Focus-Il passaggio dalla scuola secondaria di secondo grado all'Università. Rome: Miur.

Nauck, B. and J. Suckow. 2006. "Intergenerational Relationships in Cross-Cultural Comparison: How Social Networks Frame Intergenerational Relations Between Mothers and Grandmothers in Japan, Korea, China, Indonesia, Israel, Germany, and Turkey." Journal of Family Issues 27 (8): 1159-1185.

Natividad, J.N. and G.T. Cruz. 1997. "Patterns in living arrangements and familial support for the elderly in the Philippines." Asia-Pacific Population Journal 12(4): 17-34.

Ofstedal, M.B., J. Knodel and N. Chayovan. 1999. "Intergenerational support and gender: a comparison of four Asian countries." Southeast Asian Journal of Social Science 27(2): 21-41.

Ofstedal, M.B., E. Reidy and J. Knodel. 2003. "Gender differences in economic support and well-being of older Asians." PSC Research Report, no.03-540. Ann Arbor MI: PSC-University of Michigan.

Pang, E.C., M. Jordan-Marsh, M. Silverstein and M. Cody. 2003. "Health-seeking behaviours of elderly Chinese Americans: Shifts in expectations." The Gerontologist 43(6): 864-874.

Peng, I. and J. Wong. 2010. "East Asia." In The Oxford Handbook of the Welfare State, edited by F.G. Castles, S. Leibfried, J. Lewis, H. Obinger, C. Pierson, 656-670. Oxford: Oxford University Press.

Portes, A. and R. Rumbaut. 2001. Legacies: The Story of the Immigrant Second Generation. Berkeley: University of California Press. 
Portes, A. and M. Zhou 1993. The New Second Generation: Segmented Assimilation and Its Variants, Annals of the American Academy of Political and Sociale Science, vol. 530, Interminority Affairs in the U.S.: Pluralism at the Crossroads, pp. 74-96.

Quisumbing, A.R. 1994. "Intergenerational transfers in Philippine rice villages: Gender differences in traditional inheritance customs." Journal of Development Economics, 43(2): 167-195.

Rapoport, H. and F. Docquier. 2006. "The economics of migrants' remittances." In Handbook of the Economics of Giving, Reciprocity and Altruism, edited by S.C. Kolm and J. Mercier Ythier, 1135-1198. Amsterdam: Elsevier.

Rooyakers, I.N., H.G.A. De Valk and E.M. Merz. 2016. "Mother-child relations in adulthood within and across national borders. Non-western immigrants in the Netherlands." Ageing \& Society 36: 2010-2035.

Rumbaut, R.G. 1997. "Ties that bind." In Immigration and the family: Research and policy on U.S. immigrants, edited by A. Booth, A.C. Crouter and N. Landale, 3-46. Mahwah, NJ: Lawrence Erlbaum.

Schans, D. and A. Komter. 2010. "Ethnic differences in intergenerational solidarity in the Netherlands." Journal of Aging Studies 24: 194-203.

Scott, J. F. 1971. Internalization of Norms: A Sociological Theory of Moral Commitment. Englewood Cliffs: Prentice Hall.

Silverstein, M. and C. Attias-Donfut. 2010. "Intergenerational relationships of international migrants in developed nations: the United States and France." In The SAGE Handbook of Social Gerontology, edited by D. Dannefer and C. Phillipson, 177-189. London: Sage.

Silverstein, M. and X. Chen. 1999. "The impact of acculturation in Mexican-American families on the quality of adult grandchild-grandparent relationships." Journal of Marriage and Family 61: 188-198.

Silverstein, M., Z. Cong, and S. Li. 2006. "Intergenerational transfers and living arrangements of older people in rural China: Consequences for psychological wellbeing." The Journals of Gerontology: Social Sciences 61: S256-S266.

Stanley, B.S. and S. Okazaki. 1990. "Asian-American educational achievements: A phenomenon in search of an explanation." American Psychologist 45(8): 913-920.

Sun, R. 2002. "Old age support in contemporary urban China from both parents' and children's perspectives." Research on Aging 24(3): 337-359.

Thang, L.L. 2010. "Intergenerational relations: Asian perspectives." In The SAGE Handbook of Social Gerontology, edited by D. Dannefer and C. Phillipson, 202-215. London: Sage.

Treas, J. and S. Mazumdar. 2004. "Kinkeeping and caregiving: contributions from older people in immigrant families." Journal of Comparative Family Studies 35: 105-122.

Trieu, M.M. 2016. "Family obligation fulfilment among South Asian American young adults." Journal of Family Issues 37(10): 1355-1383.

Vertovec, S. 2007. Super-diversity and its implications, Ethnic and Racial Studies: 30(6): 1024-1054.

Waters, M.C. 1997. "Immigrant families at risk: Factors that undermine chances for success." In Immigration and the family: Research and policy on U.S. immigrants, edited by A. Booth, A.C. Crouter and N. Landale, 65-84. Mahwah, NJ: Lawrence Erlbaum.

Wiborg, O. N. and R.J. Møberg. 2010. "Social Origin and the risks of disadvantage in Denmark and Norway: the early life course of young adults." Work, employment and society 24(1): 105-125. 
Wolff, F.-C., S. Spilerman and C. Attias-Donfut. 2007. "Transfers from migrants to their children: Evidence that altruism and cultural factors matter." Review of Income and Wealth 53(4): 619-644.

Yount K.M. and A.M. Sibai. 2009. "Demography of Aging in Arab Countries." In International Handbook of Population Ageing. Vol. 1, edited by P. Uhlenberg, 277315. Berlin: Springer.

Zhou, M. 2009. "Conflict, coping, and reconciliation. Intergenerational relations in Chinese immigrant families." In Across generations: Immigrant families in America, edited by N. Foner, 21-46. New York: New York University Press.

Zimmer, Z. and J. Kwong. 2003. "Family size and support of older adults in urban and rural China: Current effects and future implications." Demography 40(1): 23-44. 
Table 1. Versions of vignette concerning parents' decision as to which of two children to support financially. Identification label and number of cases for each version are reported within squared parentheses

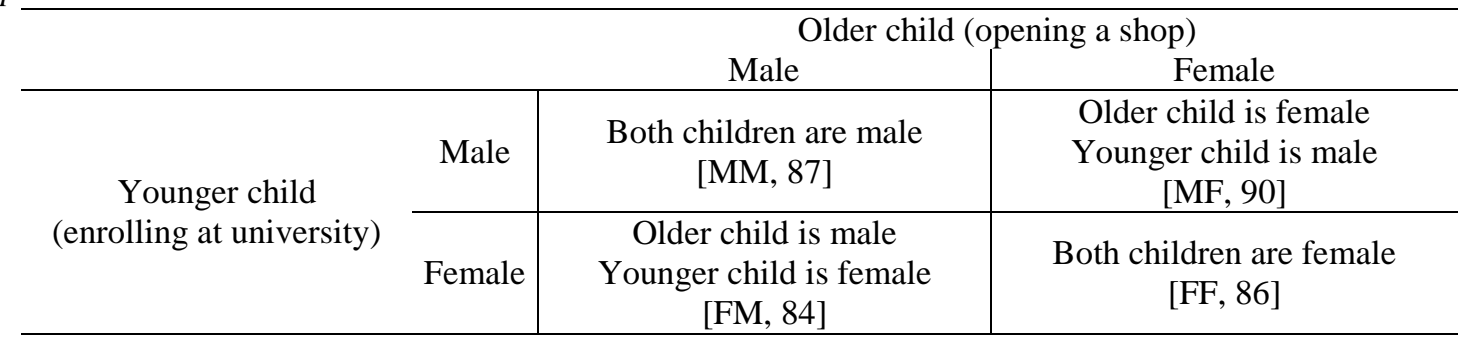


Table 2. Gender, mean age, country of birth, age group, level of education, marital status and employment status in sample subgroups and corresponding reference communities in Bologna (percentage values)

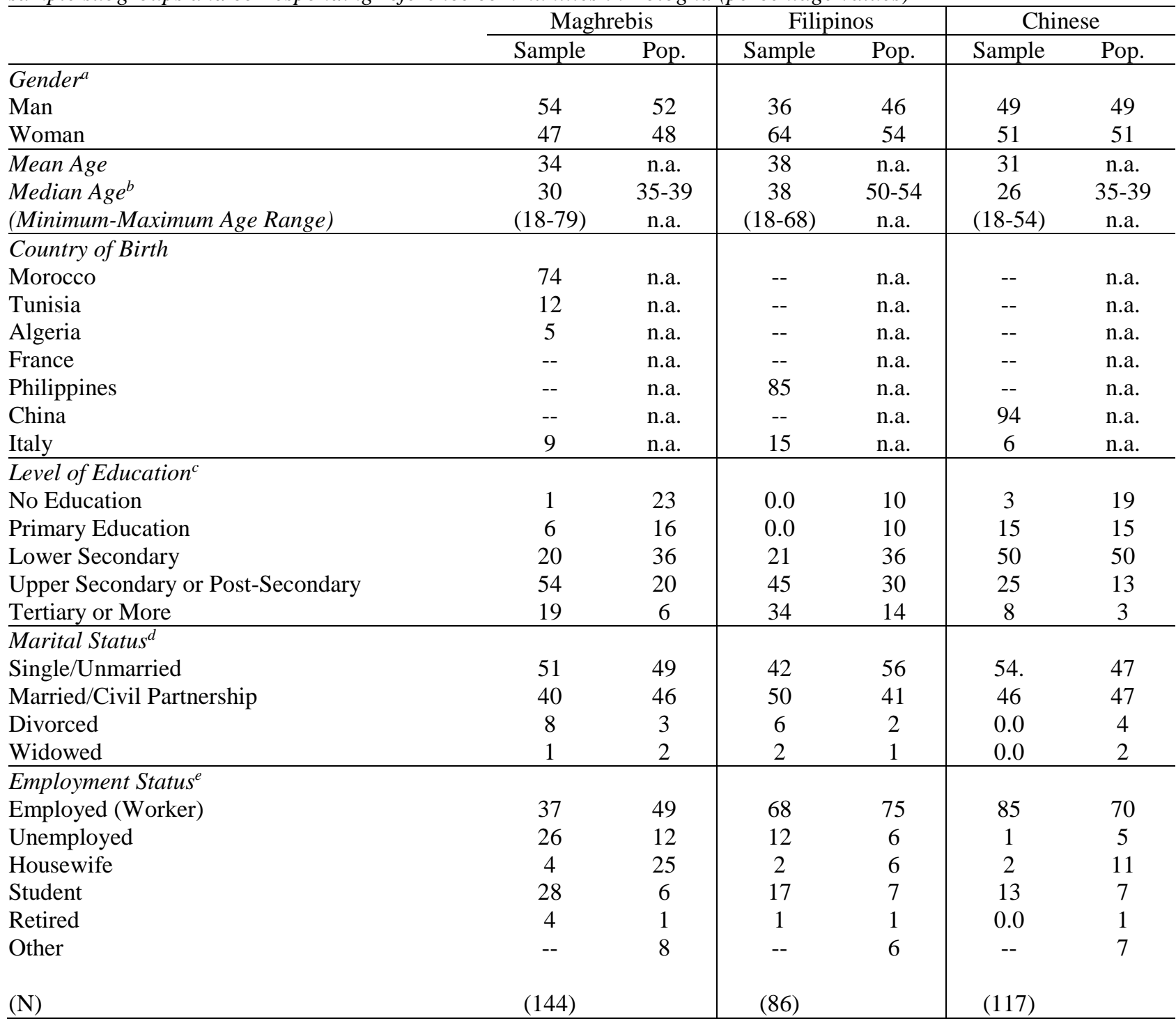

Note: Province-level data for the general population of immigrant origin are available only for gender and age. For other characteristics, population data refer to wider territories (in which the province of Bologna is located) and may include non-adults, so comparison requires caution.

${ }^{a}$ Population data refers to the Province of Bologna. Source: Istat 2015 (demo.istat.it).

${ }^{b}$ Population data refers to the Province of Bologna. Source: Census 2011 (http://daticensimentopopolazione.istat.it/Index.aspx).

${ }^{c}$ Population data refers to people of 6 years of age and more, residing in Emilia-Romagna. Source: Census 2011 (http://dati-censimentopopolazione.istat.it/Index.aspx).

${ }^{d}$ Population data refers to people residing in Emilia-Romagna. Source: Census 2011 (http://daticensimentopopolazione.istat.it/Index.aspx).

${ }^{e}$ Population data refers to people of 15 years of age and more, residing in the North-Eastern Regions. Source: Census 2011 (http://dati-censimentopopolazione.istat.it/Index.aspx).

n.a. = not available. 
Table 3. Response distributions concerning which of two children should receive financial support from parents, by immigrant group and vignette version (percentage values)

\begin{tabular}{lrrrr}
\hline & Maghrebis & Filipinos & Chinese & All \\
\hline Student & 51 & 57 & 65 & 51 \\
Worker & 35 & 34 & 4 & 33 \\
Both & 9 & 7 & - & 7 \\
None & 4 & 2 & - & 2 \\
Missing & 1 & - & 100 & 1 \\
& & & $(117)$ & 100 \\
Total & 100 & 100 & $(347)$ \\
(N) & $(144)$ & MF Version & 58 & FF Version \\
\hline Student & 56 & 57 & 35 & 57 \\
Worker & 33 & 37 & 7 & 28 \\
Both & 5 Version & -- & 12 \\
None & 5 & 4 & -- & 2 \\
Missing & 1 & 2 & -- & 1 \\
& 5 & & 100 & $(84)$ \\
Total & 100 & 100 & $(90)$ & $(96)$ \\
(N) & $(87)$ & & & \\
\hline
\end{tabular}

Table 4. Logistic regression results concerning the likelihood of stating that parents should prioritize financial support to the child wishing to enrol in a university (models A) and that parents should prioritize support to the daughter rather than the son (only vignette versions FM and MF: models B): logistic regression coefficients and (in parentheses) standard errors

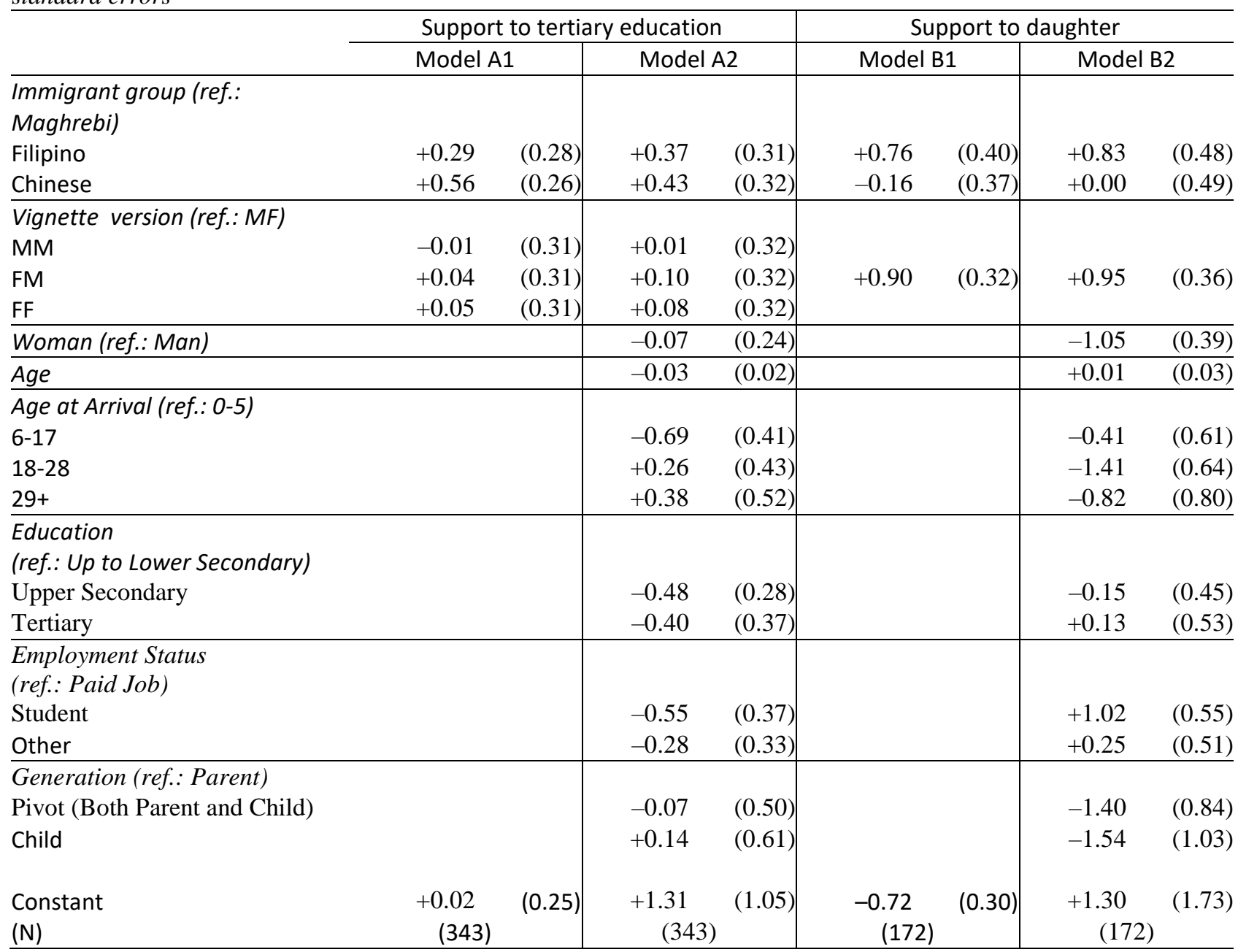


Figure 1. Predicted probabilities (0-1 scale) of prioritizing child's education over other child's business initiative or other responses (Model A2) and predicted probabilities of preferring support for daughters over sons (Model B2), by immigrant group, age of arrival in Italy and employment status
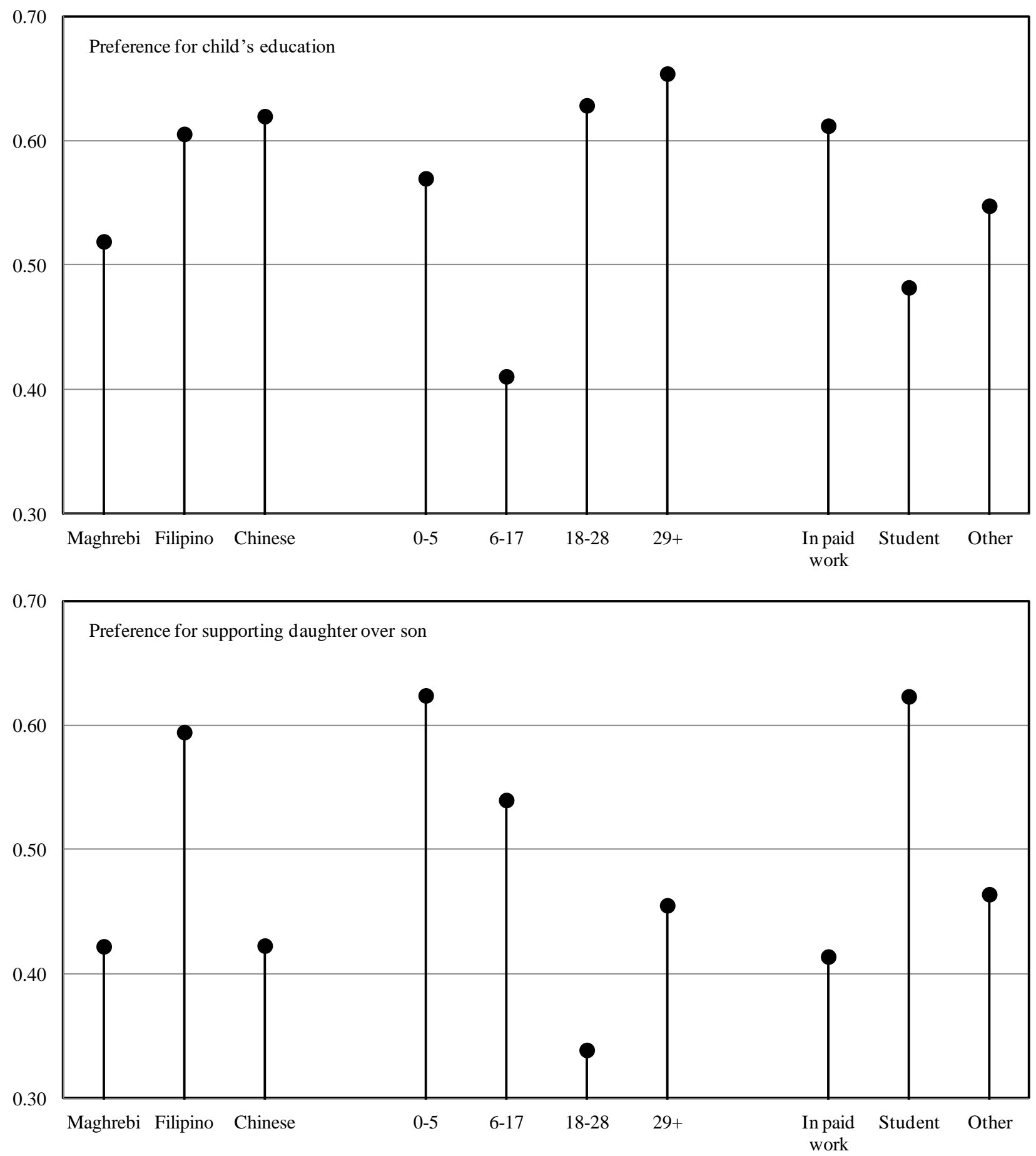
Table 5. Response distributions of reasons why parents should prioritize financial support to a child wishing to enrol in a university, by immigrant group ((absolute values; only classes with non-neglible frequencies)

\begin{tabular}{|c|c|c|c|c|}
\hline & Maghrebi & Filipino & Chinese & All \\
\hline Studying as an investment strategy & 29 & 20 & 19 & 68 \\
\hline Oldest child will have to find another job (not self-employment) & 25 & 12 & 24 & 61 \\
\hline Opening a shop can wait & 2 & 11 & 44 & 5 \\
\hline Studying is important & 15 & 18 & 22 & 55 \\
\hline Youngest child cannot miss the opportunity, one can study only when young & 15 & 4 & 34 & 5 \\
\hline Youngest child is a very good student & 10 & 2 & 9 & 2 \\
\hline Opening a shop is risky & 7 & 6 & 6 & 1 \\
\hline Youngest child can get a grant/studying is not too expensive & 6 & -- & 6 & 12 \\
\hline Getting a university degree will give prestige to child/family & 9 & -- & -- & \\
\hline
\end{tabular}

